\title{
Comparison of Three Planting Distances and Fertilizer Applications on the Yield of Pineapple Variety PR $1-67^{1}$
}

\author{
Oscar D. Ramirez and Hector Gandia ${ }^{2}$
}

\begin{abstract}
An experiment was established at Manatí, Puerto Rico, on a Bayamón fine sandy loam to determine the influence of three different planting distances and fertilizer applications on yield of the new pineapple variety PR 1-67. The three distances compared in the experiment varied only along the lines of double rows and consisted of intervals of 12,18 and 24 in, equivalent to $13,403,8,944$ and 6,701 plants per acre, respectively. Fertilizer applications were 1.5075 ton/acre for the 12-in spacing, 1.006 ton/acre for the 18-in spacing and 0.7545 ton/acre for the 24 -in planting distance in the first crop; and .4188, .2795, and .2094 ton/acre, respectively, for the second crop.

The best planting distance and fertilizer application for the plant crop was 24 in between rows and 12 in within the row with 1.5075 tons/acre of 13-3-12 fertilizer.
\end{abstract}

\section{INTRODUCTION}

A pineapple breeding program was begun by this Station in 1947 in view of the importance and need for improvement of this fruit. This work has continued to the present, its main achievement being the development of a new pineapple variety: PR 1-67 $(5,6)$.

Different varieties may respond differently to cultural practices, so re-evaluation of management requirements of new varieties are often necessary. This paper presents the results of a study undertaken to determine the influence of three different planting distances and fertilizer applications on yield of PR 1-67.

\section{MATERIAL AND METHODS}

An experiment was established at Manatí on a Bayamón fine sandy loam on December 22, 1966, to determine the effect of planting distance and rate of fertilization on yield of PR 1-67.

The soil was treated before planting with 1 gal/acre $(25 \%$ a.i.) of

${ }^{1}$ Manuscript submitted to the Editorial Board July 15, 1974.

${ }^{2}$ Plant Breeder and Horticulturist, respectively, Agricultural Experiment Station, Mayagüez Campus, University of Puerto Rico, Rio Piedras, Puerto Rico. 
Aldrin ${ }^{3}$ and $6 \mathrm{gal} / \mathrm{acre}$ of Nemagon to control soil insects (2) and nematodes (2), respectively.

The experimental design was balanced incomplete blocks (paired plots) with three treatments and six replications. Planting distances were as follows: 1) 24 in between rows and 12 in within the row; 2) 24 in between rows and 18 in within the row; and 3) 24 in between rows and 24 in within the row. Each plant received 3.6 oz of 13-3-12 fertilizer for the plant crop and $1 \mathrm{oz}$ of the same fertilizer for the second (ratoon) crop. Thus, the plants planted at $24 \times 12$ in received fertilizer at the rate of 1.5075 tons/acre in the first crop; those at $24 \times 18$ in received 1.006 tons/acre; and those at $24 \times 24$ in received 0.7545 ton/acre. The total amounts of fertilizer indicated were made to the plant crop in four applications.

The planting system was similar to the one currently used with the Red Spanish variety (3), which consists of double rows 24 in apart with a passageway 54 in wide between the double rows. The three different planting distances compared in the experiment varied only along the lines of double rows, consisting of intervals of 12,18 and 24 in equivalent to $13,403,8,944$, and 6,701 plants per acre, respectively.

The experimental plots were $19.5 \times 24 \mathrm{ft}$, and the total experimental area was approximately $117 \times 80 \mathrm{ft}$. Depending on the treatment, the number of plants per plot varied as follows: treatment 1, 144 plants; treatment 2, 96; and treatment 3, 72 .

The fruits of the first and second crops were harvested when ripe, their weight recorded and statistical analyses of the data performed.

\section{RESULTS}

FIRST CROP

\section{Effect of Treatments on Fruit Yield}

There were significant differences in yield due to varying spacing and fertilization (table 1 ). The yield obtained with maximum plant density and fertilizer application exceeded in a highly significant way the yields obtained with lower plant densities and rates of fertilizer application. Yields of pineapples planted at $24 \times 18$ in and receiving 1.0060 ton/acre of fertilizer outyielded at the $1 \%$ probability level those planted at $24 \times$ 24 in and receiving only 0.7545 ton/acre of fertilizer. Therefore, according

\footnotetext{
${ }^{3}$ Trade names are used in this publication solely for the purpose of providing specific information. Mention of a trade name does not constitute a guarantee or warranty of equipment or materials by the Agricultural Experiment Station of the University of Puerto Rico or an endorsement over other equipment or materials not mentioned.
} 
to these results $24 \times 12$ in spacing and 1.5075 tons/acre fertilizer was the best of the three practices tested, producing the highest yield of fruit. Fruit yield from the first crop increased with increasing plant density and fertilizer application. These observations are in line with results reported by Pennock (4) in Puerto Rico, Su (7) in Taiwan, Wee (8) in Malaysia, and Cannon (1) in Australia.

\section{Effect of Treatments on Fruit Size and Weight}

Data obtained with respect to average fruit size and fruit weight under each planting distance and fertilizer application are presented in table 2.

Statistical analysis of the data shows that there was no significant difference between mean weights of fruits from plants at $24 \times 12$ and 24 $\times 18 \mathrm{in}$. Fruits from plants at the $24 \times 24$ in spacing weighed more at the $1 \%$ level of probability than those at $24 \times 12$ and $24 \times 18$ in, however. Thus, the $24 \times 24$ in planting distance, with the minimum quantity of fertilizer per acre, produced the heaviest fruit. Pennock (4), Su (7), Wee (8), and Cannon (1) obtained similar results.

Fruits from plants at $24 \times 24$ in were significantly wider than those at $24 \times 12$ in. No significant differences were observed in fruit length due to planting distance or rate of fertilizer application.

TABLE 1.-Pineapple yield of first crop

\begin{tabular}{|c|c|c|c|c|c|}
\hline \multicolumn{3}{|c|}{ Treatment } & \multirow{2}{*}{$\begin{array}{l}\text { Plants/ } \\
\text { acre }\end{array}$} & \multirow{2}{*}{$\begin{array}{l}\text { Fruits/ } \\
\text { acre }\end{array}$} & \multirow[b]{2}{*}{$\begin{array}{l}\text { Yield/ } \\
\text { acre }\end{array}$} \\
\hline Number & $\begin{array}{l}\text { Planting } \\
\text { distance }\end{array}$ & $\begin{array}{l}\text { Fertilizer } \\
\text { per acre }\end{array}$ & & & \\
\hline & & Tons & Number & Number & Tons \\
\hline 1 & $24 \times 12$ in & 1.5075 & 13,403 & 9,882 & $31.28 \mathrm{a}^{1}$ \\
\hline 2 & $24 \times 18$ in & 1.0060 & 8,944 & 8,454 & $20.81 \mathrm{~b}$ \\
\hline 3 & $24 \times 24$ in & .7545 & 6,701 & 6,267 & $17.65 \mathrm{c}$ \\
\hline
\end{tabular}

${ }^{1}$ All values with the same letter do not differ significantly at the $5 \%$ level.

TABLE: 2.-Mean weight, width and length of fruit in the first crop

\begin{tabular}{cccccc}
\hline & Treatment & Fertilizer & $\begin{array}{c}\text { Mean fruit } \\
\text { weight } \\
\text { Number acre }\end{array}$ & $\begin{array}{c}\text { Mean fruit } \\
\text { width } \\
\text { distance }\end{array}$ & $\begin{array}{c}\text { Mean fruit } \\
\text { length }\end{array}$ \\
\hline & & Tons & $L b$ & In & In \\
1 & $24 \times 12 \mathrm{in}$ & 1.5075 & $4.69 \mathrm{a}^{1}$ & $5.22 \mathrm{a}$ & $5.50 \mathrm{a}$ \\
2 & $24 \times 18 \mathrm{in}$ & 1.0060 & $4.87 \mathrm{a}$ & $5.51 \mathrm{ab}$ & $5.77 \mathrm{a}$ \\
3 & $24 \times 24 \mathrm{in}$ & .7545 & $5.28 \mathrm{~b}$ & $5.60 \mathrm{~b}$ & $5.83 \mathrm{a}$ \\
\hline
\end{tabular}

'All means with the same letter do not differ significantly at the $5 \%$ level. 


\section{SECOND CROP [RATOON]}

\section{Effect of Treatments on Fruit Yield, Size and Weight}

Statistical analysis of the yield data (table 3 ) indicated that there were significant differences between the effect of the different planting distances and fertilizer applications on fruit yield. Yield of plants at $24 x$ 12 in and maximum rate of fertilization were larger at the $1 \%$ probability level than those of the plants at $24 \times 18$ and $24 \times 24$ in and lower rates of fertilization.

Just as in the first crop, $24 \times 12$ in and maximum rate of fertilizer application proved to be best among the treatments compared, but in this case the amount of fertilizer applied was less: $1 \mathrm{oz} /$ per plant vs. 3.6

TABLE 3.-Pineapple yield of the second or first ratoon crop

\begin{tabular}{|c|c|c|c|c|c|}
\hline \multicolumn{3}{|c|}{ Treatment } & \multirow{2}{*}{$\begin{array}{l}\text { Plants/ } \\
\text { acre }\end{array}$} & \multirow{2}{*}{$\begin{array}{c}\text { Fruits/ } \\
\text { acre }\end{array}$} & \multirow{2}{*}{$\begin{array}{l}\text { Yield/ } \\
\text { acre }\end{array}$} \\
\hline Number & $\begin{array}{l}\text { Planting } \\
\text { distance }\end{array}$ & $\begin{array}{l}\text { Fertilizer } \\
\text { per acre }\end{array}$ & & & \\
\hline & & Tons & Number & Number & Tons \\
\hline 1 & $24 \times 12$ in & 0.4188 & 13,403 & 9,882 & $15.09 \mathrm{a}^{1}$ \\
\hline 2 & $24 \times 18$ in & .2795 & 8,944 & 8,454 & $12.87 \mathrm{~b}$ \\
\hline 3 & $24 \times 24$ in & .2094 & 6,701 & 6,267 & $10.45 \mathrm{~b}$ \\
\hline
\end{tabular}

${ }^{1}$ All values with the same letter do not differ significantly at the $5 \%$ level.

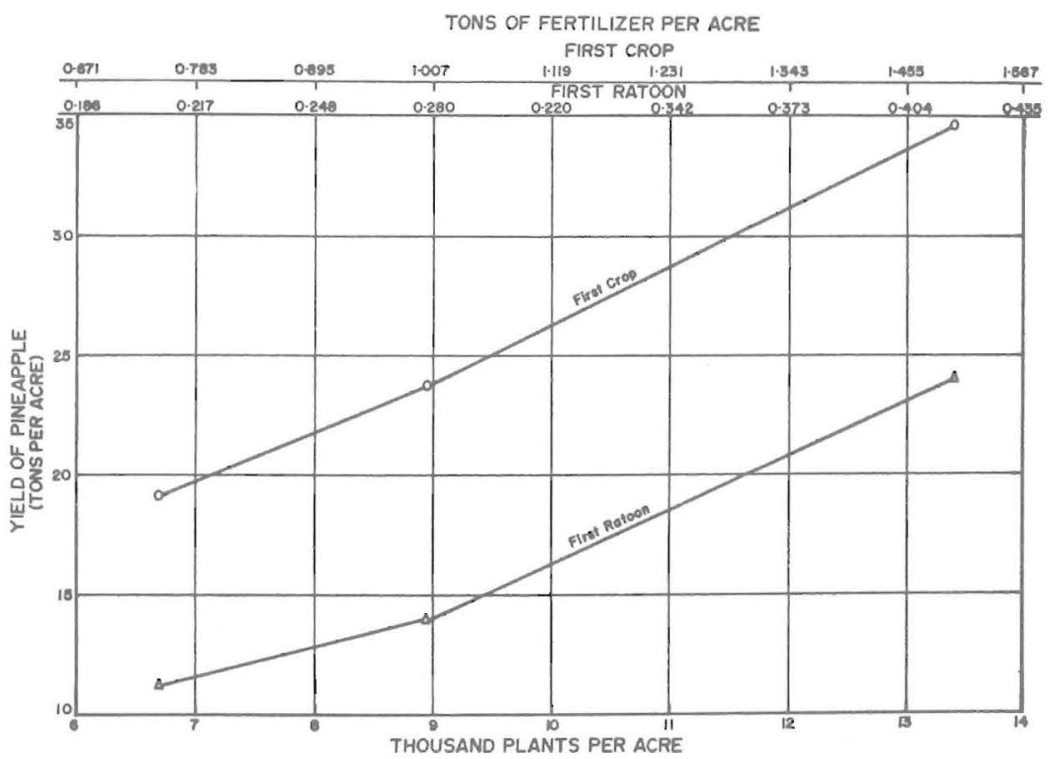

FIG, 1. - Tons of fruit per acre in the first crop and first ratoon as related to the number of plants and fertilizer applied per acre. 
PLANT SPACING, FERTILIZER, AND YIELD OF PINEAPPLE

TABLE 4.-Mean weight, width and length of fruit in the second or first ratoon crop

\begin{tabular}{|c|c|c|c|c|c|}
\hline \multicolumn{3}{|c|}{ Treatment } & \multirow{2}{*}{$\begin{array}{l}\text { Mean fruit } \\
\text { weight }\end{array}$} & \multirow{2}{*}{$\begin{array}{l}\text { Mean fruit } \\
\text { width }\end{array}$} & \multirow{2}{*}{$\begin{array}{l}\text { Mean fruit } \\
\text { length }\end{array}$} \\
\hline Number & $\begin{array}{l}\text { Planting } \\
\text { distance }\end{array}$ & $\begin{array}{l}\text { Fertilizer } \\
\text { per acre }\end{array}$ & & & \\
\hline & & Tons & $L b$ & In & In \\
\hline I & $24 \times 12$ in & 0.4188 & $3.80 \mathrm{a}^{1}$ & $5.11 \mathrm{a}$ & $5.46 \mathrm{a}$ \\
\hline 2 & $24 \times 18$ in & .2795 & $3.61 \mathrm{a}$ & $5.00 \mathrm{a}$ & $5.39 a$ \\
\hline 3 & $24 \times 24$ in & .2094 & $3.67 \mathrm{a}$ & $5.07 \mathrm{a}$ & $5.44 \mathrm{a}$ \\
\hline
\end{tabular}

${ }^{2}$ All means with the same letter do not differ significantly at the $5 \%$ level.

oz in the plant crop (fig. 1). No other differences were ascribed to the treatments tested (tables 3 and 4). Since fruit size was about the same in all cases yield was approximately proportional to the number of fruits harvested, which in turn was governed by the number of plants per acre. This was also reported by Su (7) working with variety Smooth Cayenne. Wee (8) obtained the same results in Malaysia working with the variety Singapore Spanish.

\section{RESUMEN}

El tamaño de la fruta es muy importance en la producción de la piña. En este experimento con la nueva varieda PR 1-67, se probaron tres distancias de siembra y tres aplicaciones de abono.

En la siembra de plantilla se obtuvo el rendimiento más elevado ( $31.28 \mathrm{~T}$./acre) usando la distancia más corta entre plantas (12 pulgadas) y una aplicación de abono de 1.5075 T./acre. El peso medio de fruta fue de $4.69 \mathrm{lb}$. (2.127 kg.). En el retoño, la producción más alta (15.09 T./acre) se obtuvo usando esta misma distancia con una aplicación de abono de $0.4188 \mathrm{~T}$./acre.

De las tres prácticas comparadas la mejor fue la siembra a 24 pulgadas entre hileras y 12 pulgadas entre plantas en la hilera, aplicando 1.5075 T./acre de abono del análisis 13-3-12 para la siembra de plantilla y $0.4188 \mathrm{~T}$./acre para el retoño.

\section{LITERATURE CITED}

1. Cannon, R. C., Closer spacing of pineapples, Queensland Agr. J. 83(1):575-78, 1957.

2. Compendio de Recomendaciones Técnicas para Mejores Cosechas, Pub. Mis, 1, Est. Exp. Ag., Univ. P.R., Río Piedras, P.R., Rev. 1966.

3. Gandia, H., y Samuels, G., Cultivo y Elaboración de la Piña en Puerto Rico, Bol. 145, Est. Exp. Ag., Univ. P.R. Río Piedras, P.R., octubre 1958.

4. Pennock, W., Efectos de las Distancias de Siembra sobre el Tamaño y la Calidad de la Piña, Rev. Ag. P.R., Dep. Agr. 44(1):97-99, 1956.

5. Ramírez, O. D., Gandía, H., and Vélez-Fortuño, J., Two new pineapple varieties for Puerto Rico, J. Agr. Univ. P.R. 54(3):417-428, 1970.

6. — - - $\longrightarrow$, and - - P.R. 1-67, A new pineapple selection, Fruit Varieties Hort. Dig. 26(1):13-15, 1972.

7. Su, N. R., Spacing and fertilizer levels as two dominant factors in the production of pineapples, J. Agr. Ass. China (New Ser.) 17:18-66, 1957.

8. Wee, Y. C., Planting density trials with A. comosus (L.) Merr. Var. Singapore Spanish, Malaysian Agr. J. 47(2):164-174, 1969. 